\title{
Online Learning: Student Psychological Challenges During A Pandemic Covid-19
}

\section{Norasyikin Osman, Siti Salwa Mohd Noor, Norhayati Che Hat}

To Link this Article: http://dx.doi.org/10.6007/IJARBSS/v12-i1/11636

DOI:10.6007/IJARBSS/v12-i1/11636

Received: 05 November 2021, Revised: 13 December 2021, Accepted: 27 December 2021

Published Online: 21 January 2022

In-Text Citation: (Osman et al., 2022)

To Cite this Article: Osman, N., Noor, S. S. M., \& Hat, N. C. (2022). Online Learning: Student Psychological Challenges During A Pandemic Covid-19. International Journal of Academic Research in Business and Social Sciences, 12(1), $910-918$.

\section{Copyright: (c) 2022 The Author(s)}

Published by Human Resource Management Academic Research Society (www.hrmars.com)

This article is published under the Creative Commons Attribution (CC BY 4.0) license. Anyone may reproduce, distribute, translate and create derivative works of this article (for both commercial and non0-commercial purposes), subject to full attribution to the original publication and authors. The full terms of this license may be seen at: http://creativecommons.org/licences/by/4.0/legalcode

\section{Vol. 12, No. 1, 2022, Pg. $910-918$}

Full Terms \& Conditions of access and use can be found at http://hrmars.com/index.php/pages/detail/publication-ethics 


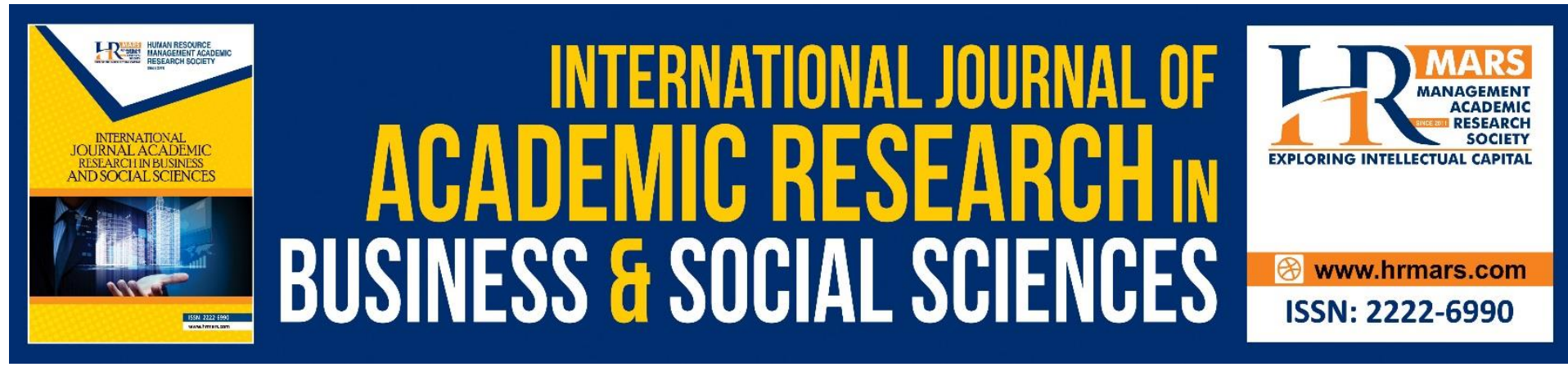

\title{
Online Learning: Student Psychological Challenges During A Pandemic Covid-19
}

\author{
Norasyikin Osman, Siti Salwa Mohd Noor, Norhayati Che Hat
}

Faculty of Languages and Communications, Sultan Zainal Abidin University

\begin{abstract}
Full online learning sessions has been actively applied in teaching and learning as a result of the Covid-19 pandemic. Various SOPs have been outlined; including social distancing in which face-to-face encounters are avoided. As such, face-to-face learning in the classroom now has shifted towards full online teaching and learning. While full online learning is the best alternative at the moment, there are various constraints and challenges that need to be faced. This study aims to examine the psychological aspects of students in pursuing online learning. The respondents of the study involved semester 1, 3, 5, and 7 students who enrolled in the Bachelor's Degree in Arabic language Studies at Sultan Zainal Abidin University (UniSZA). The students had been following full online learning for a total of 1 semester or about 14 weeks. They were instructed to answer a distributed questionnaire. In addition, the students also left comments related to the challenges faced during the online learning session. The findings of the study showed that the overall psychological aspects of students were at a moderate level when following the fully online learning sessions, while other challenges faced by students include internet access problems, unconducive environment, workload from lecturers, and lack of cooperation from teammates. As such, these findings can be used as a guide by stakeholders in order to fully improve the online learning system.
\end{abstract}

Keywords: Covid-19, Psychological Challenges, Full Online Learning

\section{Introduction}

Computer-Assisted Language Learning (CALL) has been prevalent for more than 30 years (Warschauer, 1996). CALL is defined as a process that involves students using a computer to improve students' language proficiency (Beatty, 2010). The evolution of CALL took place in the 1970s, as a result of the development of research related to the use of computers aimed at creating an appropriate language learning environment and for linguistic purposes. The advent of language labs in the 1970s provided an environment for CALL to take root. This situation is a continuation of work done in audio visual laboratories (Salaberry, 2001; Gündüz, 2005). This situation continued to develop when language classes at universities created compulsory learning sessions in the laboratory that required students to perform reinforcement exercises (Warschauer, 1996). While in 1980, the use of computers continued to gain a place, not only in educational institutions but also in private homes (Gündüz, 2005).

The use of computer or technology-based applications continues to grow rapidly in the field of education to this day. Various innovations have been developed including the 
development of technology-based modules as support materials in teaching and learning and has been used at all levels of education, including kindergartens, primary schools, secondary schools, and universities. Physical meetings, face-to-face exercises, and classroom discussions are still prioritised in the teaching and learning process, in addition to the use of technology. As a result, students and teachers can continue to meet as usual. The combination of this face-to-face teaching and learning approach and the use of technology is known as blended learning.

However, the world has been afflicted by the covid-19 pandemic since the beginning of 2020. This scenario has had a significant impact on education in Malaysia and around the world. There has been a drastic change when schools and educational institutions need to be closed to curb the spread of this virus. In any scenario, the teaching and learning process must be continued. With the rapid advancement of technology, its best use has been made to assure educational continuity. Face-to-face or blended classes (a combination of face-to-face and online) are no longer available. The only other option is to use a full online teaching and learning. According to prior research, blended learning is the greatest solution since blended learning can balance human requirements and technology. While fully online learning has its own set of limitations, including psychological and environmental considerations, it does have some advantages. The study of the human soul and mind is known as psychology (Kamarudin, 2010). In other words, it is intimately linked to the student's internal elements. External influences such as the learning environment, family members, friends, and teachers are included in the environment. However, totally online learning must be introduced because it is the only option accessible as the world is struck by the pandemic.

\section{Problem Statement and Research Objectives}

Face-to-face learning has long been a standard practise in teaching and learning, whether at the primary, secondary, or university levels. With the advancement of technology, the field of education is expanding, and technology-based learning is becoming more prevalent. According to Campenella et al (2008), the development of online learning has become a phenomenon where the construction and development of web-based courses is increasing day by day. In the field of education, the advantages and disadvantages of online have been identified especially after 2001. This situation led to blended learning to start receiving attention (Tayebinik, 2012; Zhang \& Han, 2012).

Full online learning offers a number of drawbacks and difficulties. Due to a number of issues, this totally online learning is thought to be less successful. Students' loneliness, neglect of face-to-face learning aspects, procrastination, and a lack of skills are examples of such causes.

\section{i. Loneliness}

Students feel lonely because they have to learn independently in their learning process (Graham, 2003; McDonald, 2008; Precel et al., 2009). Students expressed feelings of loneliness and no socialisation because no physical encounters took place (Sana et al., 2011). This in turn has a negative impact on their achievement (Precel et al., 2009).

\section{ii. Neglect Of Face-to-Face Learning Aspects}

Teachers and students dislike online learning because it ignores the importance of face-toface learning (Ferri et al., 2020): Adnan \& Anwar (2020): Hong \& Samimy (2010): Simamora, 2010). Students who prefer physical interactions such as those seen in face-to-face learning 
will find that learning on the line does not entirely suit their demands. Face-to-face interactions are essential for establishing mutual trust (Graham, 2003).

iii. Procrastination

Students are more likely to tend to procrastinate (Simamora, 2020: Graham, 2003). Students take all of the assignments offered with granted when learning is too flexible and not connected to time and place.

iv. Lack of Skills

Students and teachers lack the cognitive skills to make the most of all the advantages found in e-learning (Precel, Eshet-Alkalai \& Alberton, 2009). Similarly, teachers and students are less skilled in handling online learning (Ferri et al., 2020)

v. Facility and equipment constraints

To ensure that the teaching and learning process functions well, full online learning requires consistent internet access. Despite this, past research has found that students have restricted internet access and face financial difficulties in obtaining internet subscriptions (Henaku, 2020: Ferri et al., 2020; Adnan \& Anwar, 2020: Simamora, 2020).

On the difficulties raised, the purpose of this research is to ascertain the psychological challenges that students have when it comes to actively pursuing online learning. Psychological factors are crucial in ensuring that students' emotions are in excellent shape while they are learning. The best emotions will help students learn more quickly and efficiently. Other problems were studied in addition to the psychological element, particularly those related to the environment of students when pursuing online learning completely.

OBJECTIVE

This study aims to achieve the following objectives:

i. Study the psychology of students while pursuing full online learning.

ii. Assess the challenges students face in pursuing full online learning.

While the research questions are as follows:

i. What are the psychological aspects of students when following full online learning?

ii. What are the challenges faced by students while following full online learning?

\section{Methodology}

This is a survey study in which students' input on the implementation of online learning is gathered through a questionnaire. A total of 131 Bachelor of Arabic students from semesters $1,3,5$, and 7 participated in the study. After completing the online course for one semester (14 weeks), the study participants were given questionnaires. The students were asked a total of ten specific questions about psychological elements of full-time online study. A statistical analysis was performed to determine the mean score value for each item.

Students were also invited to give comments about the obstacles they had during the whole online learning experience, in addition to the questionnaire. The comments made are unrestricted and not limited to psychological considerations. Following that, these comments were analysed to derive themes relating to the problems students had when fully participating in online learning. 


\section{Findings and Discussion}

A questionnaire containing a total of 10 question items was distributed to the students. The questionnaire was then analysed to obtain the mean score for each item. The mean values obtained by each item will be interpreted with reference to the score interpretation table. There are three levels of value, namely low, medium and high. Table 1 displays the interpretation of the scores adapted from (Jamil, 2002).

Table 1Mean Score Interpretation

\begin{tabular}{cc}
\hline Mean Score & Interpretation \\
\hline $1.00-2.33$ & Low \\
\hline $2.34-3.66$ & Moderate \\
\hline $3.67-5.00$ & High \\
\hline & \multicolumn{2}{c}{ Source Jamil (2002) }
\end{tabular}

The study's findings revealed that, as shown in Table 2, the overall mean of students' psychological aspects when following online learning was at a moderate level of 3.57. Items relating to students who do not want to follow teaching and learning online had the highest mean score, which was 3.95. These data imply that students prefer to have face to face instruction in addition to online learning. Furthermore, when the online learning session was entirely at a high level of 3.86, students were unable to offer focus. Students also agreed that they quickly feel bored when following online learning with a mean score of 3.78 and felt anxious with a mean value of 3.71. Both of these items are at a high level. Students also moderately agreed with the statement that they felt lonely when following teaching and learning online completely with a mean value of 3.63. Other items that showed moderate students agreeing with the given statements included students feeling unmotivated (3.54), unmotivated (3.47), feeling depressed (3.45) tending to procrastinate (3.24) and feeling ignored when pursuing fully online learning.

These findings clearly indicate that the psychological aspects of students when pursuing online learning need to be given serious attention. This is because psychology that is not at its best will affect the learning process of students. In fact, the findings show that students will not choose online learning completely if given the choice. The Henaku (2020) study reported that students requested that online learning be completely suspended as students were unable to follow online learning well and effectively. This is due to students not being able to focus well, quickly feel bored and anxious with their learning. This situation in turn will put pressure on the students. Previous studies have also reported that students feel stressed when following online learning completely (Farooqui, 2020: Lazarevic \& Bentz, 2021: Wahyu \& Simanullang, 2020: Sahoo, 2020) In addition, student motivation also declines when compared to face-to-face learning. These findings were also reported by the study of Ferri et al (2020) and also the study of (Latifa et al., 2021). 
Table 2 Mean Score of Psychological Challenges Faced by Students while Pursuing Full Online Learning

\begin{tabular}{|c|c|c|}
\hline Item & Mean & Interpretation \\
\hline $\begin{array}{l}\text { 1. I feel lonely while following online } \\
\text { teaching and learning }\end{array}$ & 3.63 & Moderate \\
\hline $\begin{array}{l}\text { 2. I feel anxious every time I joined full } \\
\text { online teaching and learning }\end{array}$ & 3.71 & High \\
\hline $\begin{array}{l}\text { 3. I quickly got bored while following } \\
\text { online teaching and learning }\end{array}$ & 3.78 & High \\
\hline $\begin{array}{l}\text { 4. I feel stressed while following online } \\
\text { teaching and learning }\end{array}$ & 3.45 & Moderate \\
\hline $\begin{array}{l}\text { 5. I could not focus while following online } \\
\text { teaching and learning }\end{array}$ & 3.86 & High \\
\hline $\begin{array}{l}\text { 6. I could not be enthusiastic when it } \\
\text { comes to following online teaching and } \\
\text { learning }\end{array}$ & 3.54 & Moderate \\
\hline $\begin{array}{l}\text { 7. I am not motivated when following } \\
\text { online teaching and learning }\end{array}$ & 3.5 & Moderate \\
\hline $\begin{array}{l}\text { 8. I tend to postpone assigned assignments } \\
\text { while following online teaching and } \\
\text { learning }\end{array}$ & 3.24 & Moderate \\
\hline $\begin{array}{l}\text { 9. I feel like I am being ignored when } \\
\text { following online teaching and learning }\end{array}$ & 3 & Moderate \\
\hline $\begin{array}{l}10 \text { If given the choice, I would not choose } \\
\text { to follow online teaching and learning }\end{array}$ & 3.95 & High \\
\hline AVERAGE MEAN & 3.57 & \\
\hline
\end{tabular}

Aside from the psychological component, an analysis of student comments was conducted to determine the issues and problems that students have while pursuing online learning. There are four categories of problems faced by students including unsatisfactory Internet coverage, unconducive environment, workload from lecturers and lack of cooperation from teammates have been identified.

\section{i) Unsatisfactory Internet Coverage}

When it comes to the internet's issues, it's a regular topic of discussion when online learning is introduced. Students noted internet connection concerns such as unreliable access, insufficient bandwidth, and the high cost of obtaining an internet line. During the teaching and learning sessions, students who were unable to unlock the camera frequently dropped 
out of online lessons, and the audio was less clear due to the internet line's fragility. This scenario has an impact on the children' ability to learn.

"During online teaching and learning, when there was an internet disruption caused me to miss the information given by the lecturer" (P33)

"It's just that sometimes I get out of google meet due to a broken line" (P42)

"Unavoidable technical problems such as the Internet line when the time is not expected" (P61)

ii) Non - Conducive Environment

The next challenge that students face is the environment or atmosphere when pursuing online learning. Unconducive environment, noisy environment, and unfavourable residential conditions. Students with large families will be required to share a room. Students also expressed difficulty acquiring various reference materials, despite the fact that prior to the pandemic, they could locate references at the library.

Students have a variety of responsibilities in their respective residences. As youngsters, they are required to assist their parents at home, which makes it difficult to divide time. When students spend a lot of time studying and completing tasks, family members may have misunderstandings.

"Less conducive environment" (p14, p17)

"The atmosphere of the study place is sometimes noisy" (P11)

"Lots of commitment at home" (P17)

"The problem of responsibility as a child. when sitting at home, it's all wrong to want to stay in my room, but there are a lot of exams. It's hard to divide study time. when sitting in an old room, I get angry because my mother says I can't help my mother at home. the dilemma of living as a student" P30

"I face the interference of my younger siblings" (P24)

"The family does not understand my situation as a student and they even feel that I am just in the room and not doing any work. In addition, the atmosphere of the house is a bit noisy. " (P43)

"The atmosphere is not conducive for me to study calmly during the full online teaching and learning. I hope the campus can open quickly and be able to study face to face. Help us, we want to learn like before as well as get more knowledge and be able to improve our pointers." (P4)

\section{iii) Workload from Lecturers}

One of the issues is when a handful of lecturers provide a large number of assignments, evaluation techniques are not disclosed at the beginning of the semester, assignment formats are frequently changed at the last minute, and assignments are accepted unexpectedly. Furthermore, there is a lack of interaction between instructors and students.

"Lack of break time due to too many assignments." (P8)

"The assessment method is not explained in detail during the lecture. The format of assignments that often gets changed at the last minute before submission until there are students who need to repeat the assignment even though it is ready". (P18)

"There are times when all of a sudden important assignments and notifications are given at a time other than lecture time that asks students to do it at a set time" (P41) 
iv) No Cooperation from Teammates

To ensure that all group tasks run smoothly, teammates are required. There are, however, some students who refuse to commit, forcing the group leader to finish the duties alone. The group leader is burdened by this circumstance in terms of time and internet data costs. Furthermore, group discussions are difficult to conduct.

"Group assignment problems. There will be a leader when dealing with the group assignment. Leaders always have to sacrifice a lot of things. internet data and time, even worse if the group members have many excuses, (not good at doing the work, no internet, broken laptop, family matters), then work always drags time. So if the leader has to do last minute work, they have to stay up every night. what is the function of group work here." ( "(P30)

"Throughout this ODL, I have seen which members are serious and ready to help other group members and which ones are just in it for the names. Honestly, it is difficult to choose group members because many are used to the old group members formed during semester 1 "(P43)

Based on students' comments, problems related to internet access are a major issue in following online learning. Previous studies have reported many similar findings that students face the issue of poor internet access (Henaku, 2020; Ferri, Grifoni, \& Guzzo, 2020: Adnan \& Anwar, 2020: Simamora, 2020: Ullah, Ashraf M, Ashraf S, \& Ahmed 2021: Sahoo, 2020). Apart from that, the environment that does not support online learning is also a factor in the difficulty of students in following online learning. Students are in their homes with their families, causing various issues to arise, including family members who do not understand the responsibilities of students who need to attend classes online. Students also settle for various homework assignments that can - to some extent disrupt their focus. The Sahoo study, (2020) reported that students do not have a personal space at home to pursue online learning. In addition, students also expressed receiving relatively many assignments from lecturers. In less conducive conditions causes students to find it quite difficult to complete the assignment. Classmates or groups also contribute to this issue when not all classmates are able to give their best commitment in completing the assignments given by the lecturer.

\section{Conclusion}

Online learning has its own advantages and is the best alternative in this pandemic season. However, its implementation faces challenges from various aspects, namely student psychology, internet access and the environment. In general, this study reported that the psychological level of students was at a moderate level when pursuing online learning. Psychological aspects include students not being able to focus and not tending to choose online learning entirely if given a choice. While limited internet access and unconducive environment cause the learning process can not run smoothly as expected. These issues must be addressed in order to maintain educational continuity during the pandemic season. For instance, to ensure that the psychological level of students is at its best, moral support from various parties is essential. All parties involved in this matter, including students, lecturers, parents, and educational institutions, must take the necessary efforts to ensure that students can continue their studies in the best possible conditions.

\section{References}

Adnan, M., \& Anwar, K. (2020). Online Learning amid the COVID-19 Pandemic: Students' Perspectives. Online Submission, 2(1), 45-51. 
Beatty, K. (2013). Teaching \& researching: Computer-assisted language learning. Routledge.

Farooqui, S. (2020,). Education in the time of Covid-19: How institutions and students are coping, Business Standard. Retrieved from https://www.businessstandard.com/article/education/education-in-the-time-ofcovid-19-how-institutions-andstudents-are-coping-120043001575_1.html

Ferri, F., Grifoni, P., \& Guzzo, T. (2020). Online learning and emergency remote teaching: Opportunities and challenges in emergency situations. Societies, 10(4), 86

Graham, C. R., Allen, S., \& Ure, D. (2003). Blended learning environments: A review of the research literature. Unpublished manuscript, Provo, UT, 3-5.

Gündüz, N. (2005). Computer assisted language learning. Journal of Language and Linguistic Studies, 1(2), 193-214.

Henaku, E. A. (2020). COVID-19 online learning experience of college students: The case of Ghana. International Journal of Multidisciplinary Sciences and Advanced Technology, 1(2), 54-62.

Hong, K. H., \& Samimy, K. K. (2010). The influence of L2 teachers' use of CALL modes on language learners' reactions to blended learning. Calico Journal, 27(2), 328-348.

Ahmad, J. (2002). Pemupukan Budaya Penyelidikan di Kalangan Guru di Sekolah: Satu Penilaian. Tesis ljazah Kedoktoran, Fakulti Pendidikan, Universiti Kebangsaan Malaysia.

Husin, K. (2010). Psikologi pembelajaran. Kuala Lumpur: Utusan Publication.

Latifa, N. A., Lufri, L., \& Zulyusri, Z. (2021). The Problem of Online Learning in Covid-19 toward Learning Process. Bioeducation Journal, 5(1), 19-26.

Lazarevic, B., \& Bentz, D. (2021). Student perception of stress in online and face-to-face learning: the exploration of stress determinants. American Journal of Distance Education, 35(1), 2-15.

Precel, K., Eshet-Alkalai, Y., \& Alberton, Y. (2009). Pedagogical and design aspects of a blended learning course. International Review of Research in Open and Distributed Learning, 10(2).

Sahoo, S. (2020). E-readiness and perception of student teachers' towards online learning in the midst of COVID-19 pandemic. Available at SSRN 3666914

Salaberry, M. R. (2001). The use of technology for second language learning and teaching: A retrospective. The modern language journal, 85(1), 39-56.

Sana, F., Fenesi, B., \& Kim, J. A. (2011). A Case Study of the Introductory Psychology Blended Learning Model at McMaster University. Canadian Journal for the Scholarship of Teaching and Learning, 2(1), 6.

Simamora, R. M. (2020). The Challenges of online learning during the COVID-19 pandemic: An essay analysis of performing arts education students. Studies in Learning and Teaching, 1(2), 86-103

Tayebinik, M., \& Puteh, M. (2012). Blended Learning or E-learning? International Magazine on Advances in Computer Science and Telecommunications, 3 (1), 103-110.

Ullah, A., Ashraf, M., Ashraf, S., \& Ahmed, S. (2021). Challenges of Online Learning during the COVID-19 Pandemic Encountered by Sudents in Pakistan. Journal of Pedagogical Sociology and Psychology, 3(1), 36-44

Wahyu, A., \& Simanullang, R. H. (2020). Student Stress Due to Online Learning During the Covid-19 Pandemic. Jurnal Aisyah: Jurnal Ilmu Kesehatan, 5(2), 153-157.

Warschauer, M. (1996). Computer-assisted language learning: An introduction. Multimedia language teaching, 320. 